\title{
Corporate Governance Disclosure and Ownership Concentration in Non-Financial Listed Firms in Kuwait Stock Exchange (KSE)
}

\author{
Mejbel Al-Saidi ${ }^{1}$ \\ ${ }^{1}$ Accounting Department, Colleague of business studies, PAAET, Kuwait \\ Correspondence: Mejbel Al-Saidi, Accounting Department, Colleague of Business Studies, PAAET, Kuwait. \\ E-mail: AL-Saidimtmt@hotmail.com
}

Received: September 27, 2020

Accepted: November 16, $2020 \quad$ Online Published: December 5, 2020

doi:10.5539/ijef.v13n1p1

URL: https://doi.org/10.5539/ijef.v13n1p1

\begin{abstract}
This paper demonstrates the effect of ownership concentration among large shareholders on corporate governance disclosure (CGD) in Kuwait. Secondary data were collected from 82 non-financial firms listed on the Kuwait Stock Exchange in 2018. The study used an ordinary least square regression. The 35-item CGD index served as the dependent variable while the independent variables comprised four variables of ownership and four control variables. Ownership concentration by institutions and government negatively affected the CGD index; ownership concentration by blockholders or families (individuals) had no significant impact on the CGD index.
\end{abstract}

Keywords: Kuwait, corporate governance disclosure, large shareholders

\section{Introduction}

Agency theory, which was used to design the corporate governance framework, suggests that using corporate governance effectively can reduce the agency problems and lead to the disclosure of more information, thereby improving firm value. Currently, no single definition of "corporate governance" exists. Solomon and Solomon (2004) defined it as a system of internal and external mechanisms used to ensure accountability to stakeholders. Internal mechanisms include ownership structure, board of directors, and financial policies; external mechanisms include legal system, market control, and financial accounting standards. The current study examines the impact of one mechanism - ownership structure - on corporate governance disclosure for 82 non-financial firms listed on the stock exchange at the end of 2018. In this study, "corporate governance disclosure" is defined as publishing both the voluntary and mandatory information related to stakeholders (index from 35 items); ownership concentration is divided into four variables.

Studies examining the impact of ownership structure on corporate governance disclosure (CGD) are rare, thereby offering an opportunity to make an original contribution to current studies. In addition, comparing Kuwait to other countries is interesting for two reasons. First, Kuwait has diversity in investment resources, a safe business environment, and one of the oldest markets in the Gulf area, with a value estimated at $\$ 120$ billion in 2018. Historically, Kuwait has not suffered from significant political and financial problems and boasts the oldest democratic parliament in the Gulf area. Such factors provide consistent results and conclusions. Second, Kuwait's government recently introduced new rules and regulatory updates that encourage local and foreign investors to invest in Kuwait, such as the NCL, corporate governance principles, and reductions in tax rates, along with plans to upgrade the Kuwait Stock Exchange (KSE) from a frontier market to an emerging market, although Morgan Stanley Capital International (MICI) delayed this plan because of the coronavirus pandemic. Thus, the results of this study are important not only for Kuwait, but for all developing countries featuring a similar business environment.

This study adds three important contributions to CGD studies. First, to the best of the author's knowledge, no such work has been conducted in Kuwait. After an intensive search, the author found that a few studies have examined the issue of disclosure. Second, the current study examines whether differences exist between ownership concentration and CGD in Kuwaiti firms and those found in other studies in different countries. This is a new contribution as all current studies involving Kuwait have only considered the relationship between corporate governance mechanisms and firm performance or value or the impact of corporate governance mechanisms on voluntary disclosure. Third, the results of this study are expected to help regulators and the government improve CGD and ownership structure. They could also help academic researchers by bringing their 
attention to the topic of CGD.

The remainder of the paper is organized as follows: Section 2 introduces the theoretical framework, previous studies, and hypothesis development. The methodology for gathering data and a description of the data are given in Section 3. Section 4 presents the results, while Section 5 concludes the study.

\section{Literature Review}

As so few previous studies have examined the impact of ownership concentration on CGD, this section presents these few studies as well as several studies that examined voluntary disclosure from developed and developing countries for use in the hypothesis development.

\subsection{Theoretical Framework}

Several theories in the literature examine the relationship between ownership structure and CGD. However, this study examines the relationship between the ownership structure and CGD in the framework of agency theory for two reasons. First, this theory is prevalent and widely used in the literature. Second, Kuwait is a developing country with limited protection for shareholders; thus, agency conflict between small and large shareholders or between large shareholders and debtholders is expected (La Porta et al., 1999). Cotter et al. (2011) studied theories used in studying disclosure and found no grounded theory for selecting the theories relevant for all studies as it depends on the type of data and the study's objective. Rather, they concluded that "agency theory could be used to explain corporate governance disclosure" (p. 95). Agency theory argues that ownership concentration creates three types of conflicts. According to Jensen and Meckling (1976) and Shleifer and Vishny (1986), large shareholders (institutions, government, families, or individuals) improve firm disclosure because the manager is also the majority shareholder. Large shareholders could also improve firms' effectiveness because they are more capable of controlling and monitoring information (as per the monitoring hypothesis). However, an opposing argument is that large shareholders compromise disclosure because more ownership concentration leads to other types of conflict between large and small shareholders or between large shareholders and debtholders (La Porta et al., 1999). Thus, large shareholders may act for their benefit only (the expropriation hypothesis) and disclose less information.

\subsection{Previous Studies and Hypothesis Development}

Forker (1992) presented the first academic study examining the impact of corporate governance on disclosure in the UK. However, he failed to examine the impact of ownership structure on disclosure. Raffournier (1995) studied Switzerland's situation using several corporate governance mechanisms with a sample of 161 listed firms and found that ownership concentration had a negative impact. In terms of CGD, the first empirical study exploring it was conducted by Carson (1996), who examined the impact of firm characteristics on CGD using a sample of 494 firms in Australia. Anderson and Manal (2005) studied the impact of large shareholders' ownership concentration on CGD using several mechanisms and found no impact. Parsa et al. (2007), Ben-Othman and Zeghal (2010), and Mallin and Ow-Yong (2012) found similar results in different countries. In the case of Kuwait, Al-Shammari and Al-Sultan (2010) examined the relationship between corporate governance mechanisms and voluntary disclosure and found only audit committees affected voluntary disclosure

Table 1. Studies of ownership concentration and disclosure (CGD and VD)

\begin{tabular}{llll}
\hline Authors & Country & Topic & Main results \\
\hline Anderson and Manal (2005) & Sweden & CGD & OC(non) \\
Parsa et al. (2007) & UK & CGD & OC(non) \\
Arman and Yonet (2011) & Turkey & VD & FIOC(-) \\
Tsamenyi el al. (2007) & Ghana & CGD & OC(-) \\
Makhija and Patton (2004) & Czech & VD & OC(-), GOC(non) \\
Bauwhede and Willekens (2008) & EU & CGD & OC(-) \\
Haniffa and Cooke (2002) & Malaysia & VD & OC(+). IOC(non) \\
Ghazali and Weetman (2006) & Malaysia & VD & GOC(non) \\
Al-Janadi et al. (2013) & KSA & VD & GOC(non) \\
Juhmani (2013) & Bahrain & VD & OC(-), GOC(non) \\
Neifar and Halioui (2013) & Tunis & CGD & OC(-) \\
Al-Bassam et al. (2018) & KSA & CGD & OC(-), IOC(+), GOC(+) \\
Cunha and Rodrigues (2018) & Portugal & CGD & OC(-) \\
Barako (2007) & Kenya & VD & IOC(+) \\
\hline
\end{tabular}




\begin{tabular}{llll}
\hline Donnelly and Mulcahy (2008) & Ireland & VD & IOC(non) \\
Apostolou and Nanopoulos (2009) & Greek & VD & IOC(non) \\
Ben-Othman and Zeghal (2010) & 13 countries & CGD & OC(non) \\
Samaha et al. (2012) & Egypt & CGD & OC(-) \\
Eng and Mak (2003) & Singapore & VD & OC(non), GOC(+) \\
Yuen et al. (2009) & China & VD & OC(non) \\
Lakhal (2005) & France & VD & OC(-) \\
Al-Maskati and Hamdan (2017) & Bahrain & VD & OC(non) \\
Cheung et al. (2007) & HK/Thailand & VD & OC(non) \\
Akhtaruddi et al. (2009) & Malaysia & VD & OC(non) \\
Mallin and Ow-Yong (2012) & UK & CGD & IOC(non) \\
Ntim et al. (2012) & SA & CGD & OC(-), IOC(+), GOC(+) \\
Mulgrew and Reynolds (2014) & UK & CGD & IOC(+) \\
Elfeky (2017) & Egypt & VD & OC(-) \\
Vural (2018) & Sweden & VD & FIOC(-) \\
Ho and Tower (2011) & Malaysia & VD & IOC(-), FIOC(-) \\
Khanchel (2007) & USA & CGD & IOC(+) \\
Barucci and Falini (2005) & Italy & CGD & OC(-) \\
Bhuiyan and Biswas (2007) & Bangladesh & CGD & GOC(-) \\
Almanasir and Shivaraj (2017) & Jordan & CGD & IOC(+) \\
Nerantzidis and Tsamis (2017) & Greek & CGD & OC(non) \\
\hline
\end{tabular}

Note. $\mathrm{CGD}=$ corporate governance disclosure; $\mathrm{VD}=$ voluntary disclosure; $\mathrm{OC}=$ ownership concentration by large shareholders; IOC=institution ownership concentration; GOC=government ownership concentration; FIOC=families' (individuals') ownership concentration.

Table 1 presents a summary of all previous studies discussed herein. The current study aims to fill the gap identified in these theoretical and empirical studies, especially as no study included all four ownership concentrations in one study (i.e., ownership concentration by large shareholders, institutions, the government, and families [individuals]). To achieve this goal, four hypotheses were developed.

To reiterate, agency theory has two major arguments: the monitoring hypothesis and the expropriation hypothesis. However, empirically, some studies have found that large shareholders have more incentive and power to expropriate small shareholders' benefits and thus are unwilling to disclose more information. Indeed, Samaha et al. (2012), Ntim et al. (2012), Tsamenyi et al. (2007), Bauwhede and Willekens (2008), Barucci and Falini (2005), Neifar and Halioui (2013), Cunha and Rodrigues (2018), and Al-Bassam et al. (2018) found that large shareholders have more incentive and ability to expropriate small shareholders and, thus, may use their power to control the flow of information to protect their position. Meanwhile, Anderson and Manal (2005), Parsa et al. (2007), Ben-Othman and Zeghal (2010), Nerantzidis and Tsamis (2017), and Mallin and Ow-Yong (2012) found no empirical impact of large shareholders' ownership concentration on CGD. They argued that, because of their power, large shareholders can directly access firms' information without making disclosures to the public and paying more costs. Meanwhile, Mulgrew and Reynolds (2014) examined the situation in UK listed firms and found a positive relationship between the two variables. Based on the conflict between theoretical and empirical studies, the first hypothesis is:

H1: Large shareholders' ownership concentration is significantly associated with corporate governance disclosure.

Using the same theatrical perspective, previous empirical studies have produced mixed results regarding institutional investors. Al-Bassam et al. (2018), Khanchel (2007), Mallin and Ow-Yong (2012), Ntim et al. (2012), Almanasir and Shivaraj (2017), and Mulgrew and Reynolds (2014) studied the impact of institutions on CGD and found a positive influence. They argued that institutional investors could reduce agency conflict and increase the level of disclosure. Conversely, other studies have argued that institutional investors do not impact the level of disclosure because they have the ability and incentive to access the firms' information (Apostolou \& Nanopoulos, 2009; Donnelly \& Mulcahy, 2008; Mallin \& Ow-Yong, 2012). Meanwhile, some studies have argued that institutional investors are sometimes a weak mechanism and may expropriate small shareholders (Ho $\&$ Tower, 2011). Thus, the second hypothesis is:

H2: Institutions' ownership concentration is significantly associated with corporate governance disclosure. 
Following the same theoretical argument, the government has two different motivations to comply with CGD, and some empirical studies have found different results. Ntim et al. (2012) found a positive impact of government ownership concentration on CGD in South Africa; Al-Bassam et al. (2018) found similar results in Saudi Arabia's listed firms. However, several studies have found no significant relationship between government ownership and voluntary disclosure (Al-Janadi et al., 2013; Ghazali \& Weetman, 2006). Rather, they argued the main reason for disclosing less information was that government-controlled firms did not need funds from external parties because the government provided all the necessary funds. In addition, managers in government firms are not concerned about any punishment or the loss of their jobs. Yet Bhuiyan and Biswas (2007) found that ownership concentration by the government negatively affected CGD in Bangladesh. Thus, the third hypothesis is as follows:

H3: Ownership concentration by the government is significantly associated with corporate governance disclosure.

The relationship between familial (individuals') ownership and corporate disclosure reflects a nuanced relationship. Jensen and Meckling (1976) argued that, in the case of families, owners will act for the benefits of all shareholders to protect their interests (convergence of interests). Similarly, La Porta et al. (1998) and Shleifer and Vishny (1997) argued that families acted like a controlling shareholder protecting their interests and had great access to the firms' information; thus, they do not need to disclose more information for the public. The researcher found no empirical studies examining the impact of family ownership on corporate governance disclosure. However, Arman and Yonet (2011), Vural (2018), and Ho and Tower (2011) found that family ownership negatively impacted voluntary disclosure. As few studies have examined this particular variable and Kuwait's situation has not yet been explored, the final hypothesis is:

H4: Ownership concentration by families (individuals) is significantly associated with corporate governance disclosure.

\section{Methodology and Data}

This cross-sectional study used a sample of 82 non-financial firms listed on the KSE at the end of 2018. Prior to 2017, there were no corporate governance rules; using any years before that date would be not relevant. Meanwhile, at the time of this writing, not all data for 2019 was available because the coronavirus pandemic delayed the publication of financial statements. In addition, ownership data is not available for all years. The researcher collected data manually from 27 December 2018 to 1 January 2019, which was a holiday period in Kuwait. This study excluded all financial firms because of the regulations and capital structure constraining them. This approach is consistent with previous studies in the corporate governance literature. For example, Haniffa and Hudaib (2006) excluded all financial and unit trust companies from their sample because of regulatory requirement differences. The main source of our data was the KSE's online database and annual reports published by the firms. To examine the relationship between corporate governance disclosure and ownership structure in Kuwait, this study used several variables (see Table 2 ) and the following regression:

$$
C G D I=\beta 0+\beta 1 O C+\beta 2 I O C+\beta 3 G O C+\beta 4 F I O C+\beta 5 D T+\beta 6 F S+\beta 7 F A+\beta 8 I N D+\varepsilon i
$$

Table 2. Study variables

\begin{tabular}{|c|c|}
\hline Variables & Definitions \\
\hline \multicolumn{2}{|l|}{ Dependent variable } \\
\hline Corporate governance disclosure index (CGDI) & 35-item CGDI \\
\hline \multicolumn{2}{|l|}{ Independent variables } \\
\hline Ownership concentration (OC) & Percentage of ownership held by large shareholders (those who own more than 5\%) \\
\hline Ownership concentration by institutional (IOC) & Percentage of ownership held by institutions (more than $5 \%$ ) \\
\hline $\begin{array}{l}\text { Ownership concentration by the government } \\
\text { (GOC) }\end{array}$ & Percentage of ownership held by the government (more than 5\%) \\
\hline $\begin{array}{l}\text { Ownership concentration by families/individuals } \\
\text { (FIOC) }\end{array}$ & Percentage of ownership held by families and individuals (more than 5\%) \\
\hline \multicolumn{2}{|l|}{ Control variables } \\
\hline Debt ratio (DT) & Total liabilities/total assets \\
\hline Firm size (FS) & Log of total assets \\
\hline Firm age (FA) & Year since listing in KSE \\
\hline Industry classification in KSE (IND) & $\begin{array}{l}\text { Oil and gas, basic material, industrial, consumer goods, health care, consumer } \\
\text { services, telecommunications, real estate, and technology sectors }\end{array}$ \\
\hline
\end{tabular}


In terms of dependent variables, this study constructed a CGD index based on the literature review. The researcher developed a CGD checklist, based on the NCL in Kuwait, by listing requirements and international accounting standards. An individual experienced with the KSE and an academic faculty member reviewed the checklist to ensure its validity and made the necessary modifications to the final disclosure index. Thereafter, the researcher conducted a pilot study with five firms; several items were deleted because they were deemed irrelevant. The final checklist consisted of 35 items relevant to CGD in Kuwait, which were subsequently divided into five sections: ownership structure, board of directors and management, committees, audit, and other information (see Appendix Table I). Each item was given equal weight and received a score of " 1 " if disclosed and " 0 " if not. To measure the CGD, the scores of each item were summed to derive the final scores for each firm in the sample. The CGD index for each firm was calculated by dividing the total actual items in the CGD index by the maximum possible score $(35$ items $)$ : CGDI $=($ Total disclose items $\div 35)$. Higher scores indicated a higher level of CGD. Although this method is common in the literature, no general theory provides details about the selection of items to measure disclosure.

This study used four independent variables: ownership concentration by large shareholders, by institutions, by the government, and by families (individuals). All large shareholders are clearly disclosed by KSE online. This study also employed four control variables: debt, firm size, firm age, and industry type. Debt can be expected to increase the level of CGD because it increases managers' monitoring and disciplines their actions (Jensen \& Meckling, 1976). In fact, large firms and old firms have higher disclosure and agency costs than smaller and young firms because large firms can help reduce monies to be transferred from suppliers to managers. Finally, industry type can control for any other variables that may impact the CGD level (Al-Shammari \& Al-Sultan, 2010).

\section{Results and Discussion}

\subsection{Descriptive Analysis}

As this study used OLS regressions, it examined the five OLS assumptions before conducting the analysis. Table 3 shows that all relationships among variables are less than $80 \%$, meaning multicollinearity does not exist (Brooks, 2014). Testing the residuals and their plots against predicted values found no normality, linearity, heteroskedasticity, or autocorrelation.

Table 3. Pearson correlation of study variables

\begin{tabular}{|c|c|c|c|c|c|c|c|c|}
\hline Variables & GCDI & OC & IOC & GOC & FIOC & DT & FS & FA \\
\hline CGDI & 1 & & & & & & & \\
\hline OC & -0.186 & 1 & & & & & & \\
\hline $\mathrm{IOC}$ & -0.181 & $0.645^{* *}$ & 1 & & & & & \\
\hline GOC & -0.151 & 0.108 & $-0.281 *$ & 1 & & & & \\
\hline FIOC & 0.153 & 0.113 & $-0.41^{* *}$ & -0.133 & 1 & & & \\
\hline DT & 0.070 & 0.165 & 0.053 & -0.099 & $0.225^{*}$ & 1 & & \\
\hline FS & 0.042 & 0.017 & -0.018 & 0.195 & -0.098 & $0.279^{* *}$ & 1 & \\
\hline FA & $0.426^{* *}$ & -0.042 & -0.056 & 0.195 & -0.131 & 0.097 & $0.356^{* *}$ & 1 \\
\hline
\end{tabular}

Note. $* * * \mathrm{p}<1 \%, * * \mathrm{p}<5 \%,{ }^{*} \mathrm{p}<10 \%$. For the definition of the variables, see Table 2.

However, only three variables - ownership concentration by the government, ownership concentration by families and individuals, and firm size — had high skewness and kurtosis values (see Table 4). The researcher used the rank technique (normal score) and transferred these variables to normal score data (Cooke, 1998; Haniffa \& Hudaib, 2006). The researcher also used a logging technique to transform the data, but the normal scores produced better results, higher F-values, and a higher level of significant value. The CGD index indicated a mean value of $35 \%$ for the dependent variables (range: $31 \%$ to $48 \%$ ), which is better than the results of Al-Shammari and Al-Sultan (2010), whose mean value of voluntary disclosure was 19\%. Thus, Kuwaiti listed firms are increasing their disclosure over time. For independent variables, this study found that ownership concentration was $56 \%$, ownership concentration by institutions was $43 \%$, ownership concentration by the government was $4 \%$, and ownership concentration by families and individuals was $9 \%$. Clearly, ownership structure is highly concentrated in Kuwait. Furthermore, the mean value for debt was $41 \%$, for firm size was KD205174, and for firm age was 19.5 years. 
Table 4. Descriptive analysis of variables

\begin{tabular}{cccccccc}
\hline Variables & Sample & Mean & Max & Min & SD & Skewness & Kurtosis \\
\hline CGDI & 82 & 0.35 & 0.48 & 0.31 & 0.04 & 0.045 & -0.570 \\
OC & 82 & 0.56 & 0.96 & 0 & 21.5 & -0.210 & -0.377 \\
IOC & 82 & 0.43 & 0.96 & 0 & 25.1 & 0.194 & -0.591 \\
GOC & 82 & 0.04 & 0.68 & 0 & 11.3 & 3.972 & 17.546 \\
FOCI & 82 & 0.09 & 0.60 & 0 & 14.5 & 2.019 & 3.457 \\
DT & 82 & 0.41 & 0.98 & 0.01 & 0.22 & 0.260 & -0.560 \\
FS & 82 & 205174 & 3033671 & 0 & 393067 & 4.896 & 29.926 \\
FA & 82 & 19.5 & 37 & 7 & 8.66 & 0.990 & -0.107 \\
\hline
\end{tabular}

Note. For the definition of the variables, see Table 2.

\subsection{OLS Results and Discussion}

Table 5 presents the association between ownership concentration by large shareholders and corporate governance disclosure in Kuwait. The F-value was 5.304 and was significant; the $\mathrm{R}^{2}$ was $49 \%$, and the Adjusted- $\mathrm{R}^{2}$ was $40 \%$. Hypothesis 1 , which predicted a significant association between ownership concentration by large shareholders and corporate governance disclosure, was not supported. The coefficient of ownership concentration by large shareholders was insignificant $(\beta=0.121 ; p>10 \%)$, which is inconsistent with agency theory's argument that large shareholders act in their interests only and may reduce the CGD level.

They also do not care about disclosure because they can use their power to access any information they want. (Al-Bassam et al., 2018; Bauwhede \&Willekens, 2008; Neifar \& Halioui, 2013; Ntim et al., 2012; Samaha et al., 2012; Tsamenyi et al., 2007). The current study's findings also support La Porta et al. (1999), who found that large shareholders have the power to control listed firms' resources and might treat them preferentially at the expense of small shareholders. Even when examining voluntary disclosure, several studies similarly found no significant relationship between voluntary disclosure and ownership concentration by large shareholders (Akhtaruddin et al., 2009; Al-Maskati \& Hamdan, 2017; Cheung et al., 2007).

Table 5. OLS results of CGDI

\begin{tabular}{lcccc}
\hline Variables & Predicted sign & Estimated coefficient & T-value & P-value \\
\hline Constant & & 0.341 & 7.723 & 0.00 \\
OC & Significant & $\mathbf{0 . 1 2 1}$ & $\mathbf{0 . 7 7 7}$ & $\mathbf{0 . 4 3 9}$ \\
IOC & Significant & $\mathbf{- . 2 9 4}$ & $\mathbf{- 1 . 9 1 7}$ & $\mathbf{0 . 0 5 9}$ \\
GOC & Significant & $\mathbf{- 0 . 1 0 4}$ & $\mathbf{- 3 . 7 4 7}$ & $\mathbf{0 . 0 0 0}$ \\
FIOC & Significant & $\mathbf{- . 0 1 9}$ & $\mathbf{- 0 . 6 5 2}$ & $\mathbf{0 . 5 1 6}$ \\
\hline DT & & 0.012 & 0.157 & 0.516 \\
FS & & -0.019 & -1.126 & 0.263 \\
FA & & 0.080 & 5.628 & 0.000 \\
IND1 (Oil and gas) & & -0.003 & -0.050 & 0.960 \\
IND2 (Basic material) & & -0.084 & -1.748 & 0.084 \\
IND3 (Industrial) & & -0.049 & -1.598 & 0.114 \\
IND4 (consumer goods) & 0.038 & 0.614 & 0.541 \\
IND5 (Health care) & & 0.057 & 0.647 & 0.519 \\
IND6 (consumer services ) & & 0.002 & 0.049 & 0.961 \\
IND7 (Telecommunications) & & -0.008 & -0.120 & 0.904 \\
IND8 (Real estate) & -0.075 & -1.227 & 0.224 \\
R $^{2}$ & & F-value $=5.304(0.00)$ & Adj-R & 0.40 \\
\hline
\end{tabular}

Note. The excluded dummy variable (industry type in KSE) is industry number 9 (technology). For the definition of the variables, see Table 2.

Regarding hypothesis 2, this study found a significant association between ownership concentration by institutions and corporate governance. The coefficient of ownership concentration by institutions was significant $(\beta=-0.294 ; p<10 \%)$. This is consistent with the view that institutional investors have direct access to the firms' information and thus do not need to disclose more information to the public. In their study examining the impact of voluntary disclosure on institution ownership, Ho and Tower (2011) found a negative impact in Malaysia. Haniffa and Cooke (2002) found no significant relationship between institutions and disclosure while Mallin and 
Ow-Yong (2012) found no significant relationship between the two variables in the UK.

Hypothesis 3 predicted a significant association between ownership concentration by the government and corporate governance; it was also supported. The coefficient of ownership concentration by the government was significant $(\beta=-0.104 ; p<1 \%)$. This is an interesting result because the Kuwaiti government introduced new laws to increase the CGD level, yet their firms work conversely, suggesting that the Kuwaiti government wants to achieve other goals, such as solving unemployment and benefitting previous large government employees. This finding is inconsistent with the studies of Ntim et al. (2012) and Al-Bassam et al. (2018), which found a positive association between ownership concentration by the government and corporate governance disclosure in South Africa and Saudi Arabia, respectively. In the voluntary disclosure literature, several studies have found different results, such as Ghazali and Weetman (2006), Eng and Mak (2003), Al-Janadi et al. (2013), Juhmani (2013), and Makhija and Patton (2004).

Finally, Hypothesis 4 was not supported. The coefficient of ownership concentration by families (individuals) was insignificant $(\beta=-0.019 ; p>10 \%)$. Family members in Kuwait have access to inside information and do not need to make disclosures to the public. Ho and Tower (2011), Arman and Yonet (2011), and Vural (2018) also found that ownership concentration by families and individuals does not lead to higher CGD. Thus, Kuwaiti family shareholders may prefer to keep CGD low to protect their firms from competitors. In addition, the study found that debt and firm size do not affect CGD, suggesting that Kuwaiti banks and large firms do not play an effective role in increasing the level of CGD, while, firm age positively impacts CGD.

In summary, the current results differ from those presented in Table 1 as many studies showed the impact of ownership concentration on CGD but presented mixed results. The literature review offered many explanations for these differences, which can be reduced to three main reasons. First, the measurement of the dependent variable (i.e. CGD Index) differs across studies. Each study used different items according to the specific environment and country rules. Thus, an index used in a developing country is different than an index used in a developed country. The second reason is the variability of legal system environments, including particular corporate laws, organizational culture, codified requirements, and corporate governance codes. These rules differ among countries, and no one corporate governance system is relevant to all countries. Third, the differences in ownership structure may also explain the mixed results. The ownership structure is highly concentrated in developing countries but less concentrated in developed countries. Ownership concentration is an important mechanism in developing countries, where shareholder protections are very low (La Porta et al., 1999).

\section{Conclusion}

This study examined the impact of ownership concentration on CGD using a 35-item index. It divided ownership concentration into four variables. By using cross-sectional data from 82 non-financial firms listed on the KSE at the end of 2018, the study found that large shareholders in Kuwait did not act in the interest of all shareholders, but only for their benefit. This conclusion is consistent with the study of Al-Shammari (2008), who argued that the large shareholders in the Gulf Cooperation Council (GCC) are insiders and affect the level of disclosure because they have greater access to internal information.

This study established the first point for empirically testing the importance of CGD in Kuwait. As this area has received less attention from Kuwaiti researchers, the results of this study confirmed the need for more research on the relationship between CGD and ownership structure in less developed countries. Furthermore, the study findings are useful for regulators and the government. The majority of Kuwait's non-financial firms increased CGD, but they should be more transparent in the disclosure of their financial statements for CGD purposes. Regulators should also pay more attention to the role of large shareholders and require them to disclose more information regarding the firm's annual reports. Second, regulators should modify the current rules about the number of independent board members. Current rules require firms in Kuwait to have one independent director or more, but they should account for no more than $50 \%$ of all directors. The majority of current directors were chosen due to their relationship with large shareholders. Agency theory asserts that independent directors improve firm performance, thereby increasing the level of disclosure. The current results can help listed firms promote CGDs and analyze the impact of increasing large shareholders' ownership concentration. For investors, when making rational decisions, they must try to gather more information rather than depending on listed firms controlled by unqualified large shareholders.

This study has three limitations that represent promising opportunities for further studies. First, this study used data from one year for non-financial firms listed on the KSE. Future studies could use a sample of financial firms listed on the KSE or panel data. However, ownership data is not publicly available, so researchers must manually collect this information at the end of each year. Second, this study examined the relationship between ownership 
structure and CGD in the agency theory framework. Future research could further build upon the foundation of this study by adopting and applying other theories used in the literature. Finally, this study used the OLS regression to examine the impact of ownership structure on CGD; future studies might test the same relationship using a simultaneous equation method (2SLS), which Agrawal and Knoeber (1996) used to control for endogeneity. Many previous studies (e.g., Elmagrhi et al., 2020; Ntim et al., 2017) argued that the impact of governance mechanisms on corporate governance disclosure is an endogenously association that depends on many variables and firm characteristics.

\section{References}

Agrawal, A., \& Mandelker, G. (1990). Large shareholders and the monitoring of managers: The case of anti-takeover charter amendments. Journal of Financial and Quantitative Analysis, 25, 143-161. https://doi.org/10.2307/2330821

Akhtaruddin, M., Hossain, M., Hossain, M., \& Yao, L. (2009). Corporate governance and voluntary discourse in corporate annual reports of Malaysian listed firms. Journal of Applied Management Accounting Research, 7(1), 1-19.

Al-Bassam, W., Ntim, C., Opong, K., \& Downs, Y. (2018). Corporate boards and ownership structure as antecedents of corporate governance disclosure in Saudi Arabian publicly listed corporations. Business \& Society, 57(2), 335-377. https://doi.org/10.1177/0007650315610611

Al-Janadi, Y., Rahman, T., \& Omar, N. (2013). Corporate governance mechanisms and voluntary disclosure in Saudi Arabia. Research Journal of Finance \& Accounting, 4(4), 25-36.

Almanasir, A., \& Shivaraj, B. (2017). Voluntary corporate governance disclosure innovative evidence: The case of Jordan. Journal of Reviews on Global Economics, 6, 443-454. https://doi.org/10.6000/1929-7092.2017.06.45

Al-Maskati, M., \& Hamdan, A. (2017). Corporate governance and voluntary disclosure: Evidence from Bahrain. International Journal of Economics and Accounting, 8(1), 1-28. https://doi.org/10.1504/IJEA.2017.10005962

Al-Saidi, M. (2013). Ownership concentration and firm performance: the case of Kuwait. Jordan Journal of Business Administration, 9(4), 803-819. https://doi.org/10.12816/0002094

Al-Saidi, M., \& Al-Shammari, B. (2012). Corporate governance in Kuwait: An analysis in terms of grounded theory. International Journal of Disclosure and Government, 11(2), 128-160. https://doi.org/10.1057/jdg.2012.19

Al-Shammari, B. (2008). Voluntary disclosure in Kuwait corporate annual reports. Review of Business Research, 7(1), 10-30.

Al-Shammari, B., \& Al-Sultan, W. (2010). Corporate governance and voluntary disclosure in Kuwait. International Journal of Disclosure and Governance, 7(3), 262-280. https://doi.org/10.1057/jdg.2010.3

Anderson, M., \& Manal, D. (2005). Corporate governance disclosure by Swedish listed corporations [Unpublished master's degree thesis]. Jonkoping International Business School, Sweden.

Apostolou, A., \& Nanopoulos, K. (2009). Voluntary accounting disclosure and corporate governance: Evidence from Greek listed firms. International Journal of Accounting and Finance, 1(4), 395-414. https://doi.org/10.1504/IJAF.2009.029146

Arman, K., \& Yonet, N. (2011). Impact of board characteristics and ownership structure on voluntary disclosure (Working paper). Istanbul.

Barako, D. (2007). Determinants of voluntary disclosure in Kenyan companies' annual reports. African Journal of Business Management, 1(5), 113-128.

Barucci, E., \& Falini, J. (2005). Determinants of corporate governance in the Italian financial market. Economic Notes, 34(3), 371-405. https://doi.org/10.1111/j.0391-5026.2005.00155.x

Bauwhede, H., \& Willekens, M. (2008). Disclosure on corporate governance in the European Union. Corporate Governance: An International Review, 16(2), 101-115. https://doi.org/10.1111/j.1467-8683.2008.00671.x

Ben-Othman, H., \& Zeghal, D. (2010). Investigating transparency and disclosure determinants at firm level in MENA emerging markets. International Journal of Accounting, Auditing, and Performance Evaluation, 6(4), 368-396. https://doi.org/10.1504/IJAAPE.2010.036152 
Bhuiyan, M. H. U., \& Biswas, P. K. (2007). Corporate governance and reporting: An empirical study of listed companies in Bangladesh. Journal of Business Studies, 28(1), 1-32.

Brooks, C. (2014). Introductory econometrics for finance. Cambridge University Press. https://doi.org/10.1017/CBO9781139540872

Carson, E. (1996). Corporate governance disclosure in Australia: the state of play. Australian Accounting Review, 6(2), 3-10. https://doi.org/10.1111/j.1835-2561.1996.tb00010.x

Cheung, Y., Thomas, J., Limpaphayom, P., \& Zhou, L. (2007). Do investors really value corporate governance? Evidence from the Hong Kong market. Journal of International Financial Management and Accounting, 18(2), 86-122. https://doi.org/10.1111/j.1467-646X.2007.01009.x

Cooke, T. (1998). Regression analysis in accounting disclosure studies. Accounting and Business Research, 28(3), 209-224. https://doi.org/10.1080/00014788.1998.9728910

Cotter, J., Lokman, N., \& Najah, M. M. (2011). Voluntary disclosure research: Which theory is relevant? The Journal of Theoretical Accounting Research, 6(2), 77-95.

Cunha, V., \& Rodrigues, L. L. (2018). Determinants of structure of corporate governance disclosure in Portugal. Review of Business Management, 20(3), 338-360. https://doi.org/10.7819/rbgn.v0i0.3359

Donnelly, R., \& Mulcahy, M. (2008). Board structure, ownership, and voluntary disclosure in Ireland. Corporate Governance an International Review, 16(5), 416-429. https://doi.org/10.1111/j.1467-8683.2008.00692.x

Elfeky, M. (2017). The extent of voluntary disclosure and its determinants in emerging markets: Evidence from Egypt. The Journal of Finance and Data Science, 1-15. https://doi.org/10.1016/j.jfds.2017.09.005

Elmagrhi, M., Ntim, C., Wang, Y., Abdou, H., \& Zalata, A. (2020). Corporate governance disclosure indexexecutive pay nexus: The moderating effect of governance mechanisms. European Management Review, 17(1), 121-152. https://doi.org/10.1111/emre.12329

Eng, L., \& Mak, Y. (2003). Corporate governance and voluntary disclosure. Journal of Accounting and Public Policy, 22(3), 301-325. https://doi.org/10.1016/S0278-4254(03)00037-1

Forker, J. (1992). Corporate governance and disclosure quality. Accounting and Business Research, 22(86), 111-124. https://doi.org/10.1080/00014788.1992.9729426

Ghazali, N., \& Weetman, P. (2006). Perpetuating traditional influences: Voluntary disclosure in Malaysia following the economic crisis. Journal of International Accounting, Auditing, and Taxation, 15, 226-248. https://doi.org/10.1016/j.intaccaudtax.2006.08.001

Haniffa, R., \& Cooke, T. (2002). Culture, corporate governance, and disclosure in Malaysian corporations. ABACUS, 38(3), 317-349. https://doi.org/10.1111/1467-6281.00112

Haniffa, R., \& Hudaib, M. (2006). Governance structure and firm performance of Malaysian companies. Journal of Business Finance and Accounting, 33, 1034-1062. https://doi.org/10.1111/j.1468-5957.2006.00594.x

Ho, P., \& Tower, G. (2011). Ownership structure and voluntary disclosure in corporate annual reports of Malaysian listed firms. Corporate Ownership \& Control, 8(2), 296-312. https://doi.org/10.22495/cocv8i2c2p6

Jensen, M. C., \& Meckling, W. H. (1976). Theory of the firm: Managerial behavior, agency costs and ownership structure. Journal of Financial Economics, 3(3), 305-360. https://doi.org/10.1016/0304-405X(76)90026-X

Juhmani, O. (2013). Ownership structure and corporate voluntary disclosure: Evidence from Bahrain. International Journal of Accounting and Financial Reporting, 3(2), 133-148. https://doi.org/10.5296/ijafr.v3i2.4088

Khanchel, I. (2007). Corporate governance: Measurement and determinant analysis. Managerial Auditing Journal, 22(8), 740-760. https://doi.org/10.1108/02686900710819625

La Porta, R., Lopez-de-Silanes, F., \& Shleifer, A. (1999). Corporate ownership around the world. Journal of Finance, 54(2), 471-517. https://doi.org/10.1111/0022-1082.00115

La Porta, R., Lopez-de-Silanes, F., Shleifer, A., \& Vishny, R. (1998). Law and finance. Journal of Political Economy, 106(2), 1113-1155. https://doi.org/10.1086/250042

Lakhal, F. (2005). Voluntary earning disclosure and corporate governance: Evidence from France. Review of Accounting and Finance, 4(3), 64-85. https://doi.org/10.1108/eb043431 
Makhija, A., \& Patton, J. (2004). The impact of firm ownership structure on voluntary disclosure: Empirical evidence from Czech annual reports. Journal of Business, 77(3), 457-491. https://doi.org/10.1086/386526

Mallin, C., \& Ow-Yong, K. (2012). Factors influencing corporate governance disclosure: Evidence from alternative investment market (AIM) companies in the UK. European Journal of Finance, 18(6), 515-533. https://doi.org/10.1080/1351847X.2011.601671

Mulgrew, M., \& Reynolds, R. (2014). Corporate governance disclosure quality: Exploratory evidence from the UK. Corporate Ownership \& Control, 11(2), 120-135. https://doi.org/10.22495/cocv11i2p9

Neifar, S., \& Halioui, K. (2013). Determinants of corporate governance disclosure: The case of Tunisian firms listed on the Tunis Stock Exchange. International Journal of Finance and Accounting, 2(3), 174-183.

Nerantzidis, M., \& Tsamis, A. (2017). Going back to go forward: on studying the determinants of corporate governance disclosure. Corporate Governance International Journal of Business in Society, 17(3), 365-402. https://doi.org/10.1108/CG-07-2016-0145

Ntim, C. G., Opong, K. K., \& Danbolt, J. (2012). The relative value relevance of shareholder versus stakeholder corporate governance disclosure policy reforms in South Africa. Corporate Governance: An International Review, 20(1), 84-105. https://doi.org/10.1111/j.1467-8683.2011.00891.x

Ntim, C. G., Soobaroyen, T., \& Broad, M. J. (2017). Governance structures, voluntary disclosures and public accountability: The case of UK higher education institutions. Accounting, Auditing \& Accountability Journal, 30(1), 65-118. https://doi.org/10.1108/AAAJ-10-2014-1842

Parsa, S., Chong, G., \& Isimoya, E. (2007). Disclosure of governance information by small and medium-sized companies. Corporate Governance (Bradford), 7(5), 635-648. https://doi.org/10.1108/14720700710827211

Raffournier, B. (1995). The determinants of voluntary financial disclosure by Swiss listed companies. European Accounting Review, 4(2), 261-280. https://doi.org/10.1080/09638189500000016

Samaha, K., Dahawy, K., \& Hussainey, K. (2012). The extent of corporate governance disclosure and its determinants in a developing market: The case of Egypt. Advances in Accounting, 28(1), 168-178. https://doi.org/10.1016/j.adiac.2011.12.001

Shleifer, A., \& Vishny, R. (1986). Large shareholders and corporate control. Journal of Political Economy, 94, 461-488. https://doi.org/10.1086/261385

Shleifer, A., \& Vishny, R. (1997). A survey of corporate governance. The Journal of Finance, 52(2), 737-783. https://doi.org/10.1111/j.1540-6261.1997.tb04820.x

Solomon, J., \& Solomon, A. (2004). Corporate governance and accountability. John Wiley\& Sons Ltd.

Tsamenyi, M., Enninful-Adu, E., \& Onumah, J. (2007). Disclosure and corporate governance in developing countries: Evidence from Ghana. Managerial Auditing Journal, 22(3), 319-334. https://doi.org/10.1108/02686900710733170

Vural, D. (2018). Disclosure practices by family firms: Evidence from Swedish publicly listed firms. Accounting in Europe, 15(3), 347-373. https://doi.org/10.1080/17449480.2018.1479531

Yuen, D., Liu, M., Zhang, X., \& Lu, C. (2009). A case study of voluntary disclosure by Chinese enterprises. Asian Journal of Finance and Accounting, 1(2), 118-145. https://doi.org/10.5296/ajfa.v1i2.121 


\section{Appendix}

\section{Appendix 1. Corporate Governance Disclosure (CGD) Items}

\begin{tabular}{|c|c|c|}
\hline Item & CGD group & Details \\
\hline 1 & \multirow{6}{*}{ Ownership structure (6 items) } & Distribution of ownership by size of shareholder \\
\hline 2 & & Name of shareholders owning $5 \%$ or more \\
\hline 3 & & Directors' ownership \\
\hline 4 & & Shareholding by senior managers \\
\hline 5 & & Voting rights \\
\hline 6 & & Change in ownership structure \\
\hline 7 & \multirow{13}{*}{$\begin{array}{l}\text { Board of directors and } \\
\text { management ( } 13 \text { items })\end{array}$} & Board functions \\
\hline 8 & & Types of transactions that need board approval \\
\hline 9 & & Board members' names \\
\hline 10 & & When the directors joined the firm \\
\hline 11 & & Role of independent board members \\
\hline 12 & & Information about the directorship of other boards \\
\hline 13 & & Board size \\
\hline 14 & & Election system of board members \\
\hline 15 & & Meeting dates and attendance \\
\hline 16 & & Listing of the senior managers \\
\hline 17 & & Year of joining the firm \\
\hline 18 & & Who the CEO is \\
\hline 19 & & The CEO's qualification and experience \\
\hline 20 & \multirow{4}{*}{$\begin{array}{l}\text { Committees } \\
\text { (4 items) }\end{array}$} & Names of the committees \\
\hline 21 & & Committees' role \\
\hline 22 & & Role of audit committee \\
\hline 23 & & Number of independent members on the audit committee \\
\hline 24 & \multirow{4}{*}{ Auditors (4 items) } & Information about the auditors \\
\hline 25 & & Audit fees \\
\hline 26 & & Non-audit services \\
\hline 27 & & Who appointed the auditor \\
\hline 28 & \multirow{8}{*}{ Other information (8 items) } & Related party transactions \\
\hline 29 & & The firm's plan and strategy \\
\hline 30 & & Internal control processes and procedures \\
\hline 31 & & Presentation of financial statement and reports \\
\hline 32 & & How to manage risk \\
\hline 33 & & Number of employees and their safety \\
\hline 34 & & Corporate social responsibility (CSR) \\
\hline 35 & & Environment policy \\
\hline
\end{tabular}

\section{Copyrights}

Copyright for this article is retained by the author(s), with first publication rights granted to the journal.

This is an open-access article distributed under the terms and conditions of the Creative Commons Attribution license (http://creativecommons.org/licenses/by/4.0/). 